\title{
Typhochrestus acoreensis
}

\author{
Assessment by: Borges, P.A.V. \& Cardoso, P.
}

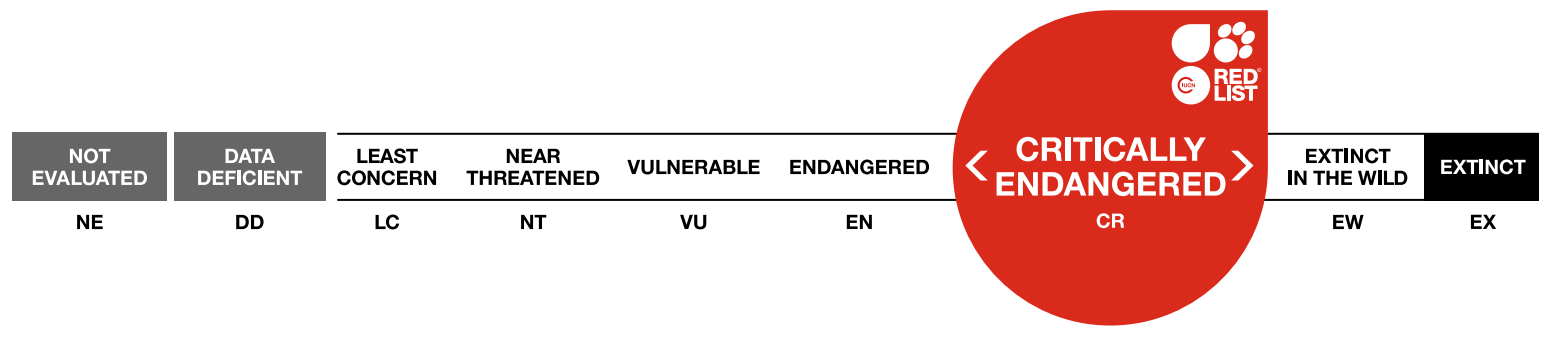

View on www.iucnredlist.org

Citation: Borges, P.A.V. \& Cardoso, P. 2020. Typhochrestus acoreensis. The IUCN Red List of Threatened Species 2020: e.T58048304A58060952. https://dx.doi.org/10.2305/IUCN.UK.20203.RLTS.T58048304A58060952.en

Copyright: (C 2020 International Union for Conservation of Nature and Natural Resources Reproduction of this publication for educational or other non-commercial purposes is authorized without prior written permission from the copyright holder provided the source is fully acknowledged.

Reproduction of this publication for resale, reposting or other commercial purposes is prohibited without prior written permission from the copyright holder. For further details see Terms of Use.

The IUCN Red List of Threatened Species ${ }^{T M}$ is produced and managed by the IUCN Global Species Programme, the IUCN Species Survival Commission (SSC) and The IUCN Red List Partnership. The IUCN Red List Partners are: Arizona State University; BirdLife International; Botanic Gardens Conservation International; Conservation International; NatureServe; Royal Botanic Gardens, Kew; Sapienza University of Rome; Texas A\&M University; and Zoological Society of London.

If you see any errors or have any questions or suggestions on what is shown in this document, please provide us with feedback so that we can correct or extend the information provided. 


\section{Taxonomy}

\begin{tabular}{|c|c|c|c|c|}
\hline Kingdom & Phylum & Class & Order & Family \\
\hline Animalia & Arthropoda & Arachnida & Araneae & Linyphiidae \\
\hline
\end{tabular}

Scientific Name: Typhochrestus acoreensis Wunderlich, 1992

\section{Taxonomic Source(s):}

Platnick, N.I. 2014. The World Spider Catalog, Version 14.5. P. Merrett \& H.D. Cameron (eds). American Museum of Natural History. Available at: http://research.amnh.org/iz/spiders/catalog/index.html. (Accessed: 31 March 2014).

\section{Assessment Information}

Red List Category \& Criteria: Critically Endangered B1ab(i,ii,iii,v) ver 3.1

Year Published: 2020

Date Assessed: $\quad$ September 28, 2017

\section{Justification:}

Typhochrestus acoreensis is a single-island endemic species, restricted to Terceira Island (Azores, Portugal) (Borges et al. 2010). It is a rare species, with a restricted Extent of Occurrence (EOO) (4-24 km ${ }^{2}$ ) and Area of Occupancy (AOO) (4-24 $\left.\mathrm{km}^{2}\right)$, but it is likely to be at the upper end of this estimate. The species occurs in a single patch of native forest (at Biscoito da Ferraria Reserve). There is a continuing decline in the EOO, AOO, extent and quality of habitat as well as the number of mature individuals as a result of the invasions of non-native plants and the impact of Cryptomeria japonica plantations, with the destruction of the main original site. Therefore, we suggest as future measures of conservation: (1) a long-term monitoring plan of the species; (2) control of invasive species, and (3) avoid the expansion of Cryptomeria japonica plantations in the Pico Alto area. The species is assessed as Critically Endangered (CR).

\section{Geographic Range}

\section{Range Description:}

Typhochrestus acoreensis is a single-island endemic species restricted to Terceira island (Azores, Portugal) (Borges et al. 2010), known from Natural Forest Reserve of Biscoito da Ferraria (Natural Park of Terceira). The Extent of Occurrence (EOO) is $4-24 \mathrm{~km}^{2}$ and the maximum estimated Area of Occupancy (AOO) is $4-24 \mathrm{~km}^{2}$.

\section{Country Occurrence:}

Native, Extant (resident): Portugal (Azores) 


\section{Distribution Map}

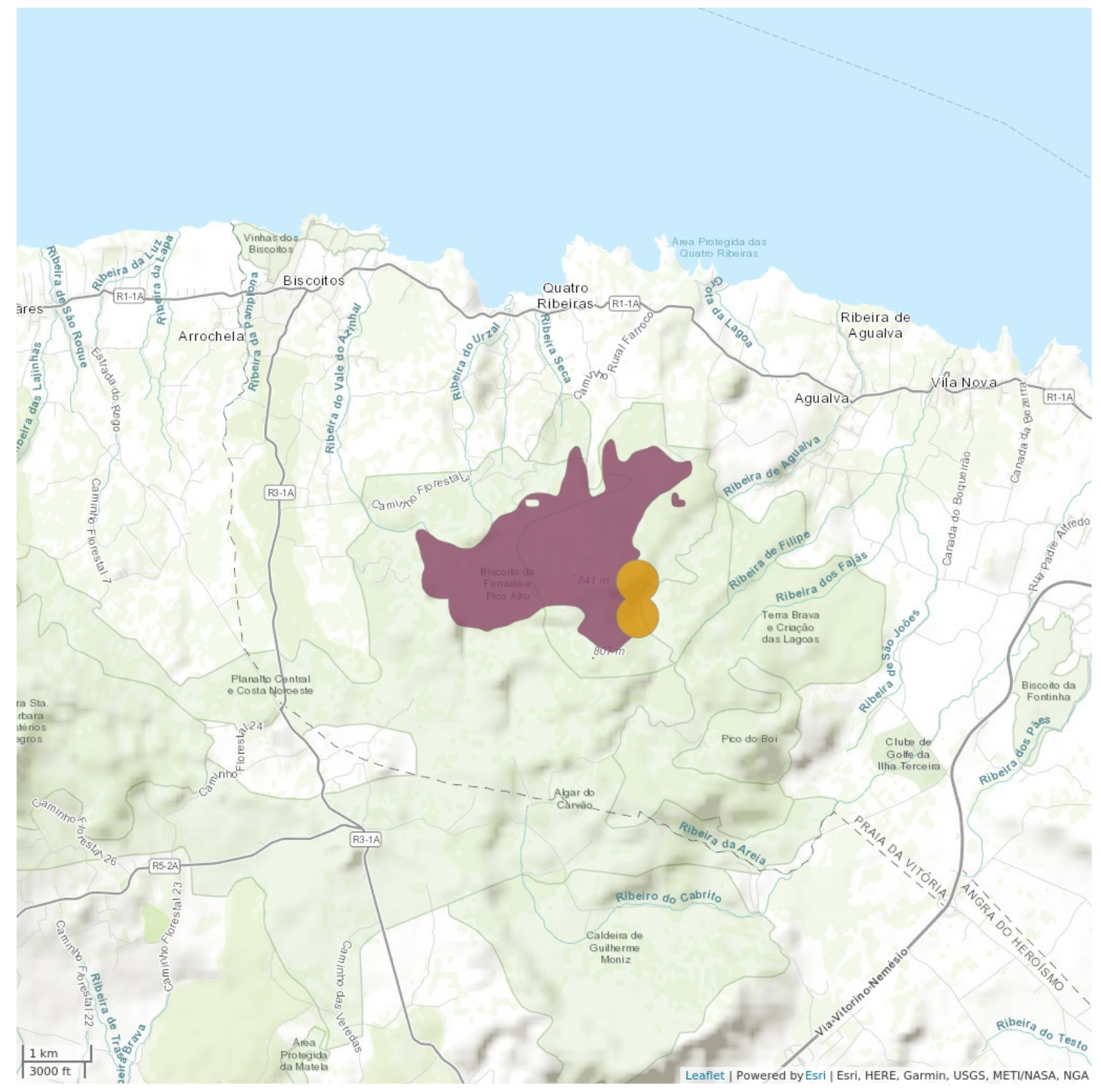

Legend

EXTANT (RESIDENT)

POSSIBLY EXTANT (RESIDENT)
Compiled by:

Azorean Biodiversity Group 2018

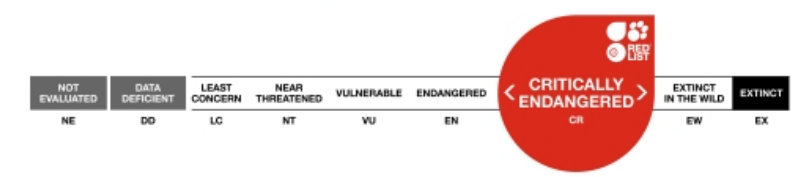

\section{8:

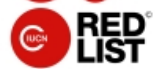

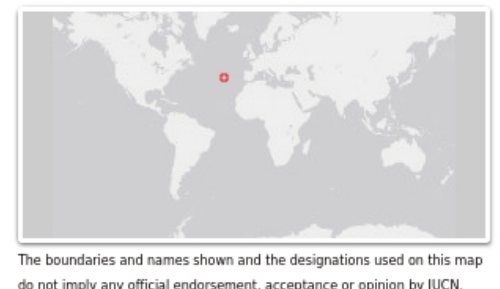




\section{Population}

This is a very rare species and only known from a single sustainable subpopulation. After its scientific description, no individuals were found during BALA project intensive sampling between 1999 and 2010 (Borges et al. 2016) and SLAM traps (2012-2016) (Borges et al. 2017). Therefore, a continuing decline in the number of mature individuals is inferred from monitoring schemes and from the ongoing habitat degradation due to invasions of alien plants (namely Hedychium gardnerianum) and a plantation of Cryptomeria japonica that was setup in the historical site, destroying most of it.

Current Population Trend: Decreasing

\section{Habitat and Ecology (see Appendix for additional information)}

The species is restricted to a hyper-humid native forest, building the sheet weaver web in the ground between holes and the trunks of Juniperus brevifolia and Laurus azorica. The ground is also covered with mosses (with the dominance of Sphagnum spp. in some areas) and ferns. The species is active during the night.

Systems: Terrestrial

\section{Threats (see Appendix for additional information)}

In the past, the species has probably strongly declined due to changes in habitat size and quality (Triantis et al. 2010). Currently, invasive plants Hedychium gardnerianum and Rubus ulmifolius are dramatically changing the structure of the forest. Based on Ferreira et al. (2016) the habitat will further decline as a consequence of climate change (increasing number of droughts and habitat shifting and alteration). The management of surrounding habitats, namely for Cryptomeria japonica plantations, may have also an impact on individuals.

\section{Conservation Actions (see Appendix for additional information)}

The species is not protected by regional law. However, its habitat is in a regionally protected area (Natural Park of Terceira). Degraded areas, degraded due to invasive plant species should be restored and a strategy needs to be developed to address the current threats from invasive species, and Cryptomeria japonica plantations in the Pico Alto area, and the future threat from climate change. Formal education and awareness is needed to allow future investments in restored habitats invaded by invasive plants; while further research is needed into its ecology and life history in order to find additional specimens at more sites within the area dominated by native forest and obtain adequate information on population size, distribution and trends. An area-based management plan is also necessary for the most disturbed sites, including invertebrate monitoring to contribute to a potential species recovery plan. Monitoring every ten years using the BALA protocol will inform about habitat quality (see e.g. Gaspar et al. 2011).

\section{Credits}

Assessor(s): $\quad$ Borges, P.A.V. \& Cardoso, P.

Reviewer(s): $\quad$ Russell, N. 
Contributor(s): $\quad$ Lamelas-López, L. \& Mendonca, E.

Authority/Authorities: IUCN SSC Spider and Scorpion Specialist Group 


\section{Bibliography}

Borges, P.A.V., Costa, A., Cunha, R., Gabriel, R., Gonçalves, V., Martins, A.F., Melo, I., Parente, M., Raposeiro, P., Rodrigues, P., Santos, R.S., Silva, L., Vieira, P. and Vieira, V. 2010. A list of the terrestrial and marine biota from the Azores. Princípia, Cascais.

Borges, P.A.V., Gaspar, C., Crespo, L., Rigal, F., Cardoso, P., Pereira, F., Rego, C., Amorim, I.R., Melo, C., Aguiar, C., André, G., Mendonça, E., Ribeiro, S.P., Hortal, J., Santos, A.M., Barcelos, L., Enghoff, H., Mahnert, V., Pita, M.T., Ribes, J., Baz, A., Sousa, A.B., Vieira, V., Wunderlich, J., Parmakelis, A., Whittaker, R.A., Quartau, J.A., Serrano, A.R.M. \& Triantis, K.A. 2016. New records and detailed distribution and abundance of selected arthropod species collected between 1999 and 2011 in Azorean native forests. Biodiversity Data Journal 4(e10948): 1-84.

Borges, P.A.V., Pimentel, R., Carvalho, R., Nunes, R., Wallon, S. \& Ros Prieto, A. 2017. Seasonal dynamics of arthropods in the humid native forests of Terceira Island (Azores). Arquipelago Life and Marine Sciences 34: 105-122.

Ferreira, M.T., Cardoso, P., Borges, P.A.V., Gabriel, R., Azevedo, E.B., Reis, F., Araújo, M.B. and Elias, R.B. 2016. Effects of climate change on the distribution of indigenous species in oceanic islands (Azores). Climate Change 138(3-4): 603-615.

Gaspar, C., Gaston, K.J., Borges, P.A.V. and Cardoso, P. 2011. Selection of priority areas for arthropod conservation in the Azores archipelago. Journal of Insect Conservation 15: 671-684.

IUCN. 2020. The IUCN Red List of Threatened Species. Version 2020-3. Available at: www.iucnredlist.org. (Accessed: 10 December 2020).

Triantis, K.A., Borges, P.A.V., Ladle, R.J., Hortal, J., Cardoso, P., Gaspar, C., Dinis, F., Mendonça, E., Silveira, L.M.A., Gabriel, R., Melo, C., Santos, A.M.C., Amorim, I.R., Ribeiro, S.P., Serrano, A.R.M., Quartau, J.A. and Whittaker, R.J. 2010. Extinction debt on oceanic islands. Ecography 33(2): 285-294.

\section{Citation}

Borges, P.A.V. \& Cardoso, P. 2020. Typhochrestus acoreensis. The IUCN Red List of Threatened Species 2020: e.T58048304A58060952. https://dx.doi.org/10.2305/IUCN.UK.2020-

3.RLTS.T58048304A58060952.en

\section{Disclaimer}

To make use of this information, please check the Terms of Use.

\section{External Resources}

For Supplementary Material, and for Images and External Links to Additional Information, please see the Red List website. 


\section{Appendix}

\section{Habitats}

(http://www.iucnredlist.org/technical-documents/classification-schemes)

\begin{tabular}{|c|c|c|c|}
\hline Habitat & Season & Suitability & $\begin{array}{l}\text { Major } \\
\text { Importance? }\end{array}$ \\
\hline 1. Forest $->1.4$. Forest - Temperate & Resident & Suitable & Yes \\
\hline
\end{tabular}

\section{Threats}

(http://www.iucnredlist.org/technical-documents/classification-schemes)

\begin{tabular}{|c|c|c|c|c|}
\hline Threat & Timing & Scope & Severity & Impact Score \\
\hline \multirow[t]{2}{*}{$\begin{array}{l}\text { 2. Agriculture \& aquaculture }->2.2 \text {. Wood \& pulp } \\
\text { plantations }->2.2 .2 \text {. Agro-industry plantations }\end{array}$} & Ongoing & Minority (50\%) & Rapid declines & $\begin{array}{l}\text { Medium } \\
\text { impact: } 6\end{array}$ \\
\hline & Stresses: & \multicolumn{3}{|c|}{$\begin{array}{l}\text { 1. Ecosystem stresses }->1.1 \text {. Ecosystem conversion } \\
\text { 1. Ecosystem stresses }->1.2 \text {. Ecosystem degradation } \\
\text { 1. Ecosystem stresses }->1.3 \text {. Indirect ecosystem effects } \\
\text { 2. Species Stresses }->\text { 2.1. Species mortality } \\
\text { 2. Species Stresses }->\text { 2.2. Species disturbance }\end{array}$} \\
\hline \multirow{2}{*}{$\begin{array}{l}\text { 8. Invasive and other problematic species, genes \& } \\
\text { diseases }->8.1 \text {. Invasive non-native/alien } \\
\text { species/diseases }->8.1 .2 \text {. Named species } \\
\text { (Hedychium gardnerianum) }\end{array}$} & Ongoing & $\begin{array}{l}\text { Majority (50- } \\
90 \%)\end{array}$ & $\begin{array}{l}\text { Slow, significant } \\
\text { declines }\end{array}$ & $\begin{array}{l}\text { Medium } \\
\text { impact: } 6\end{array}$ \\
\hline & Stresses: & \multicolumn{3}{|c|}{$\begin{array}{l}\text { 1. Ecosystem stresses }->1.1 \text {. Ecosystem conversion } \\
\text { 1. Ecosystem stresses }->1.2 \text {. Ecosystem degradation } \\
\text { 1. Ecosystem stresses }->1.3 \text {. Indirect ecosystem effects } \\
\text { 2. Species Stresses }->2.1 \text {. Species mortality } \\
\text { 2. Species Stresses }->2.2 \text {. Species disturbance } \\
\end{array}$} \\
\hline \multirow{2}{*}{$\begin{array}{l}\text { 8. Invasive and other problematic species, genes \& } \\
\text { diseases }->8.1 \text {. Invasive non-native/alien } \\
\text { species/diseases }->8.1 .2 \text {. Named species (Rubus } \\
\text { ulmifolius) }\end{array}$} & Ongoing & Minority (50\%) & $\begin{array}{l}\text { Causing/could } \\
\text { cause fluctuations }\end{array}$ & Low impact: 5 \\
\hline & Stresses: & \multicolumn{3}{|c|}{$\begin{array}{l}\text { 1. Ecosystem stresses }->1.2 \text {. Ecosystem degradation } \\
\text { 1. Ecosystem stresses }->1.3 \text {. Indirect ecosystem effects } \\
\text { 2. Species Stresses }->2.2 \text {. Species disturbance }\end{array}$} \\
\hline \multirow[t]{2}{*}{$\begin{array}{l}\text { 11. Climate change \& severe weather }->11.1 \text {. Habitat } \\
\text { shifting \& alteration }\end{array}$} & Future & Whole (>90\%) & Rapid declines & $\begin{array}{l}\text { Medium } \\
\text { impact: } 6\end{array}$ \\
\hline & Stresses: & \multicolumn{3}{|c|}{$\begin{array}{l}\text { 1. Ecosystem stresses }->1.2 \text {. Ecosystem degradation } \\
\text { 1. Ecosystem stresses }->1.3 \text {. Indirect ecosystem effects } \\
\text { 2. Species Stresses }->2.1 \text {. Species mortality } \\
\text { 2. Species Stresses }->2.2 \text {. Species disturbance }\end{array}$} \\
\hline
\end{tabular}

\section{Conservation Actions in Place}

(http://www.iucnredlist.org/technical-documents/classification-schemes) 


\begin{tabular}{|l|}
\hline Conservation Action in Place \\
\hline In-place research and monitoring \\
\hline Action Recovery Plan: No \\
\hline Systematic monitoring scheme: Yes \\
\hline In-place land/water protection \\
\hline Conservation sites identified: Yes, over entire range \\
\hline Percentage of population protected by PAs: $91-100$ \\
\hline Area based regional management plan: No \\
\hline Occurs in at least one protected area: Yes \\
\hline
\end{tabular}

\section{Conservation Actions Needed}

\section{(http://www.iucnredlist.org/technical-documents/classification-schemes)}

\section{Conservation Action Needed}

1. Land/water protection $->1.1$. Site/area protection

2. Land/water management -> 2.1. Site/area management

2. Land/water management -> 2.2. Invasive/problematic species control

2. Land/water management $->2.3$. Habitat \& natural process restoration

4. Education \& awareness $->4$.1. Formal education

4. Education \& awareness $->4.3$. Awareness \& communications

5. Law \& policy -> 5.1. Legislation -> 5.1.3. Sub-national level

\section{Research Needed}

(http://www.iucnredlist.org/technical-documents/classification-schemes)

\section{Research Needed}

1. Research $->1.2$. Population size, distribution \& trends

1. Research $->1.3$. Life history \& ecology

2. Conservation Planning -> 2.2. Area-based Management Plan

3. Monitoring $->$ 3.1. Population trends

3. Monitoring $->$ 3.4. Habitat trends

\section{Additional Data Fields}




\section{Distribution}

Estimated area of occupancy (AOO) $\left(\mathrm{km}^{2}\right): 4-24$

Continuing decline in area of occupancy (AOO): Yes

Extreme fluctuations in area of occupancy (AOO): Unknown

Estimated extent of occurrence (EOO) $\left(\mathrm{km}^{2}\right): 4-24$

Continuing decline in extent of occurrence (EOO): Yes

Extreme fluctuations in extent of occurrence (EOO): No

Number of Locations: 1

Continuing decline in number of locations: No

Extreme fluctuations in the number of locations: No

Lower elevation limit (m): 352

Upper elevation limit (m): 793

\section{Population}

Continuing decline of mature individuals: Yes

Population severely fragmented: No

Habitats and Ecology

Continuing decline in area, extent and/or quality of habitat: Yes

Generation Length (years): 1 


\section{The IUCN Red List Partnership}

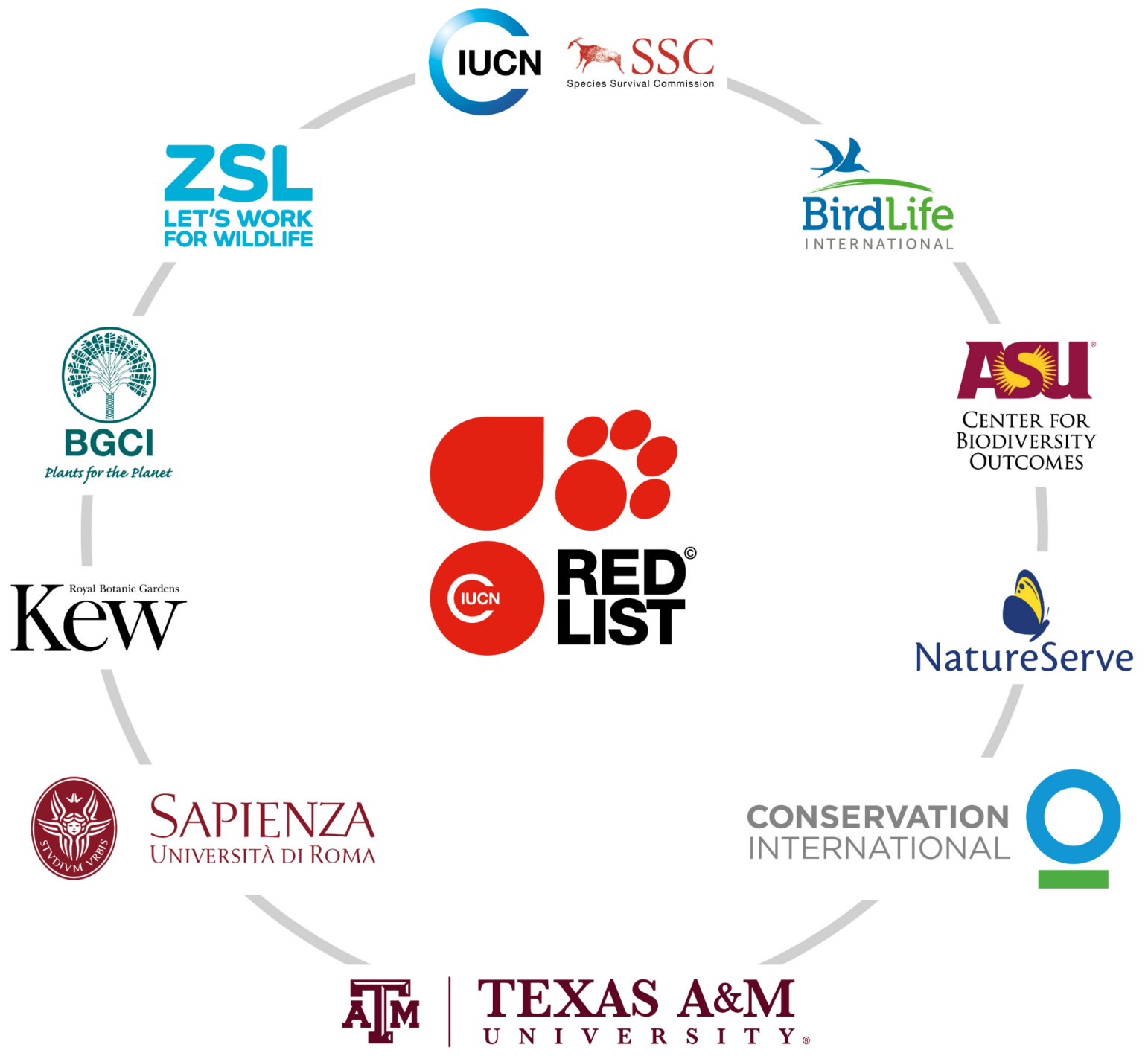

The IUCN Red List of Threatened Species ${ }^{\mathrm{TM}}$ is produced and managed by the IUCN Global Species Programme, the IUCN Species Survival Commission (SSC) and The IUCN Red List Partnership.

The IUCN Red List Partners are: Arizona State University; BirdLife International; Botanic Gardens Conservation International; Conservation International; NatureServe; Royal Botanic Gardens, Kew; Sapienza University of Rome; Texas A\&M University; and Zoological Society of London. 